University of Wollongong

Research Online

Australian Institute for Innovative Materials -

Papers

Australian Institute for Innovative Materials

$1-1-2018$

Metal-oxygen bonds: stabilizing the intermediate species towards practical Li-air batteries

Yuyang Hou

University of Wollongong, yh879@uowmail.edu.au

Yuqing Liu

University of Wollongong, yl037@uowmail.edu.au

Zhen Zhou

Nankai University, zhouzhen@nankai.edu.cn

Lili Liu

University of Wollongong, II422@uowmail.edu.au

Haipeng Guo

University of Wollongong, hg476@uowmail.edu.au

See next page for additional authors

Follow this and additional works at: https://ro.uow.edu.au/aiimpapers

Part of the Engineering Commons, and the Physical Sciences and Mathematics Commons

Research Online is the open access institutional repository for the University of Wollongong. For further information contact the UOW Library: research-pubs@uow.edu.au 


\title{
Metal-oxygen bonds: stabilizing the intermediate species towards practical Li-air batteries
}

\author{
Abstract \\ Rechargeable nonaqueous Li-air batteries are attracting much attention due to their far higher theoretical \\ energy density than lithium-ion batteries. However, Li-air batteries suffers from poor round-trip efficiency, \\ low rate capability and poor cycle life. To reduce charge overpotentials by understanding reaction \\ mechanism and to operate in ambient air instead of pure oxygen are prerequisites to realization of \\ practical Li-air batteries. Here, we demonstrate a practical Li-air battery using Mo $2 \mathrm{C} / \mathrm{CNT}$ as a potential \\ promoter with high round-trip efficiency $(\sim 80 \%)$ and improved cycling performance (40 cycles) because \\ Mo $2 \mathrm{C}$ stabilizes the intermediate species from reduction of both 02 and $\mathrm{CO} 2$. The stabilization via \\ formation of $\mathrm{Mo}-\mathrm{O}$ bonds prevents further reduction and disproportionation of intermediate species to \\ generate crystalline $\mathrm{Li} 2 \mathrm{O} 2$ and $\mathrm{Li} 2 \mathrm{CO} 3$, thus reducing the charge overpotentials normally caused by \\ the decomposition of crystalline $\mathrm{Li} 2 \mathrm{O} 2$ and $\mathrm{Li} 2 \mathrm{CO} 3$. In all, this work provides improved understanding \\ of the general role of solid promoters and enables rational design of promoters towards practical Li-air \\ batteries.

\section{Disciplines} \\ Engineering | Physical Sciences and Mathematics

\section{Publication Details} \\ Hou, Y., Liu, Y., Zhou, Z., Liu, L., Guo, H., Liu, H., Wang, J. \& Chen, J. (2018). Metal-oxygen bonds: stabilizing \\ the intermediate species towards practical Li-air batteries. Electrochimica Acta, 259 313-320.
}

\section{Authors}

Yuyang Hou, Yuqing Liu, Zhen Zhou, Lili Liu, Haipeng Guo, Hua-Kun Liu, Jiazhao Wang, and Jun Chen 


\section{Metal-oxygen bonds: stabilizing the intermediate species towards practical Li-air batteries}

Yuyang Hou ${ }^{\mathrm{a}}$, Yuqing Liu ${ }^{\mathrm{a}}$, Zhen Zhou ${ }^{\mathrm{b}}$, Lili Liuc, Haipeng Guo ${ }^{\mathrm{c}}$, Huakun Liu ${ }^{\mathrm{c}}$, Jiazhao Wang ${ }^{\mathrm{c}, *}$, and Jun Chen ${ }^{\mathrm{a}, *}$

${ }^{a}$ ARC Centre of Excellence for Electromaterials Science, Intelligent Polymer Research Institute, Australian Institute of Innovative Materials, Innovation Campus, University of Wollongong, Squires Way, North Wollongong, NSW 2500, Australia.

${ }^{\mathrm{b}}$ Key Laboratory of Advanced Energy Material Chemistry (Ministry of Education), Institute of New Energy Material Chemistry, Collaborative Innovation Center of Chemical Science and Engineering (Tianjin), School of Materials Science and Engineering, National Institute for Advanced Materials, Nankai University, Tianjin 300350, China.

${ }^{c}$ Institute for Superconducting and Electronic Materials, Australian Institute of Innovative Materials, Innovation Campus, University of Wollongong, Squires Way, North Wollongong, NSW 2500, Australia.

Keywords: metal-oxygen bonds; lithium-air batteries; stabilization; intermediate product; molybdenum carbide

\section{Corresponding authors:}

JunChen (junc@uow.edu.au), Jiazhao Wang (jiazhao@uow.edu.au). 


\begin{abstract}
Rechargeable nonaqueous Li-air batteries are attracting much attention due to their far higher theoretical energy density than lithium-ion batteries. However, Li-air batteries suffers from poor round-trip efficiency, low rate capability and poor cycle life. To reduce charge overpotentials by understanding reaction mechanism and to operate in ambient air instead of pure oxygen are prerequisites to realization of practical Li-air batteries. Here, we demonstrate a practical Li-air battery using $\mathrm{Mo}_{2} \mathrm{C} / \mathrm{CNT}$ as a potential promoter with high round-trip efficiency $(\sim 80 \%)$ and improved cycling performance ( 40 cycles) because $\mathrm{Mo}_{2} \mathrm{C}$ stabilizes the intermediate species from reduction of both $\mathrm{O}_{2}$ and $\mathrm{CO}_{2}$. The stabilization via formation of Mo-O bonds prevents further reduction and disproportionation of intermediate species to generate crystalline $\mathrm{Li}_{2} \mathrm{O}_{2}$ and $\mathrm{Li}_{2} \mathrm{CO}_{3}$, thus reducing the charge overpotentials normally caused by the decomposition of crystalline $\mathrm{Li}_{2} \mathrm{O}_{2}$ and $\mathrm{Li}_{2} \mathrm{CO}_{3}$. In all, this work provides improved understanding of the general role of solid promoters and enables rational design of promoters towards practical Li-air batteries.
\end{abstract}




\section{Introduction}

The Li-air battery, as one of the most promising power sources for electric vehicles, has attracted increasing attention over the last decade, owing to its specific energy density, which is 3-5 times as high as that of the state-of-the-art lithium ion batteries $[1,2]$. Certain factors, however, such as sluggish reaction kinetics, chemical instability of electrolytes, and moisture susceptibility, act as major obstacles to the realization of practical Li-air batteries. One major challenge for the realization of the Li-air batteries is reducing large voltage hysteresis and thus improving low round-trip efficiency through a clear understanding of the reaction mechanism of the catalyst. Although numerous catalysts have been recently developed to reduce the large charge-discharge voltage gap to increase the energy efficiency [3-6], a better understanding of the detailed mechanisms of the oxygen reduction reaction (ORR) and the oxygen evolution reaction (OER) still requires further systematic investigation. Given the mechanism of discharge product growth and decomposition, it is somewhat hard to envision how electrocatalysis could actually occur. As is well known, electrocatalysis occurs when an active catalytic site lowers the barrier of the kinetic limiting step in the mechanism, but the catalytic site itself is not changed during the reaction. It is difficult to see, however, how $\mathrm{Li}_{2} \mathrm{O}_{2}$ and $\mathrm{LiO}_{2}$ could have enough mobility for true catalysis to occur, owing to their insolubility in the electrolyte. There is no true electrocatalysis in the same way as is observed for aqueous ORR/OER, where soluble products are formed, but added nanoparticles could have some beneficial effects on the morphology and charge transport at higher currents and capacities [7]. If there were such particles, however, such as platinum on the surface of carbon, they would rapidly be covered up by solid $\mathrm{Li}_{2} \mathrm{O}_{2}$ or $\mathrm{LiO}_{2}$, and the dominant electrochemistry then becomes simply the $\mathrm{Li}-\mathrm{O}_{2}$ ORR on $\mathrm{Li}_{2} \mathrm{O}_{2}$ or $\mathrm{LiO}_{2}$. The material design which has been already successfully applied in aqueous ORR/OER needs to be changed, because the 
intermediate product is soluble in aqueous electrolyte, which could not affect the catalytic sites of nanocatalyst particles.

Noble metal and transitions metal oxides have been extensively investigated as catalysts for Li$\mathrm{O}_{2}$ batteries, and several catalytic mechanisms have been proposed. Yao et al. proposed that enhancement of $\mathrm{Li}_{2} \mathrm{O}_{2}$ oxidation is mediated by chemical conversion of $\mathrm{Li}_{2} \mathrm{O}_{2}$ with slow oxidation kinetics to a lithium oxide [6]. Wang et al. proposed that partial oxidation of ruthenium catalyst can stabilize the highly unstable peroxide/superoxide that is caused by the lithium-deficient $\mathrm{Li}_{2} \mathrm{O}_{2}$ (or $\mathrm{Li}_{2-x} \mathrm{O}_{2}$ ), forming $\mathrm{Li}_{2-x} \mathrm{O}_{2}$ (solid)-Ru at the interface [8]. Recently, a one-electron charge process in lithium oxygen batteries was observed, and it was reported to be responsible for low overpotential during the charge process. $\mathrm{Lu}$ et al. demonstrated that the $\mathrm{LiO}_{2}$ formed in the $\mathrm{Li}-\mathrm{O}_{2}$ battery is stable enough so that the battery could be repeatedly charged and discharged with a very low charge potential, and they proposed that the intermetallic compound $\mathrm{Ir}_{3} \mathrm{Li}$ and $\mathrm{LiO}_{2}$ both have a similar orthorhombic lattice, so it may act as a template for the growth of crystalline $\mathrm{LiO}_{2}$ [9]. Meanwhile, Trahey et al. proposed that $\mathrm{MnO}_{2}$ can act as a " $\mathrm{Li}_{x} \mathrm{O}_{y}$-storage material", reversibly storing lithium-oxide species during the $\mathrm{Li}_{-} \mathrm{O}_{2}$ reactions, based on density functional theory (DFT) computations, and in this case, the transition metal oxides in lithium air batteries do not act as "catalyst" in the traditional sense of facilitating a chemical reaction while remaining unchanged, but actually undergo chemical and structural changes themselves as well [10]. All the above shows the synergetic effect between the catalyst and the intermediate discharge product $\mathrm{Li}_{x} \mathrm{O}_{2}$, which possibly can account for the reduced charge overpotential due to the solid-state reaction in the discharge process. Even though extensive studies have been conducted to elucidate the role of conventional solid catalysts, the operating mechanism remains elusive and controversial in $\mathrm{Li}-\mathrm{O}_{2}$ batteries. 
The other major challenge to realize practical Li-air batteries is how to eliminate the influence of $\mathrm{CO}_{2}$ and moisture when operate in ambient air. Supposing that moisture, which is known to fatally degrade electrolyte and lithium anode, is removed by an air dehydration membrane [11], $\mathrm{CO}_{2}$ should have most influence on the chemistry of Li-air batteries among various constituents of air. Despite its low concentration in air, the high solubility of $\mathrm{CO}_{2}$ in organic electrolytes results in the huge possibility of $\mathrm{CO}_{2}$ being incorporated into battery reaction [12]. To exclusively investigate and understand the operating mechanism of $\mathrm{CO}_{2}$, a rechargeable $\mathrm{Li}-\mathrm{CO}_{2}$ battery was proposed and extensively studied based on the reversible reaction of $4 \mathrm{Li}+3 \mathrm{CO}_{2}=2 \mathrm{Li}_{2} \mathrm{CO}_{3}+\mathrm{C}$ [13-18]. As a wide band-gap insulator and insoluble discharge product, $\mathrm{Li}_{2} \mathrm{CO}_{3}$ causes a high overpotential (> $4.0 \mathrm{~V}$ vs. $\left.\mathrm{Li} / \mathrm{Li}^{+}\right)$to decompose in charge.

Our previous studies have shown that $\mathrm{Mo}_{2} \mathrm{C} /$ carbon nanotube (CNT) could stabilize $\mathrm{CO}_{2}$ reduction intermediate to generate amorphous discharge product in discharge, avoiding ultimate formation of $\mathrm{Li}_{2} \mathrm{CO}_{3}$. The stabilized discharge product could decompose at low potentials $(\sim 3.5$ V vs. $\left.\mathrm{Li} / \mathrm{Li}^{+}\right)$in charge, efficiently reducing charge overpotential and $\mathrm{CO}_{2}$ evolution barrier in Li$\mathrm{CO}_{2}$ batteries [19]. Somewhat differently, it is still under debate whether $\mathrm{Mo}_{2} \mathrm{C}$ can have any effect on charge and how $\mathrm{Mo}_{2} \mathrm{C}$ improve oxygen evolution in $\mathrm{Li}-\mathrm{O}_{2}$ batteries. Kwak et al. demonstrated that $\mathrm{Mo}_{2} \mathrm{C}$ could increase the electrical efficiency and improve the cycling performance of $\mathrm{Li}-\mathrm{O}_{2}$ batteries, owing to the formation of metallic non-crystalline $\mathrm{MoO}_{3}$-like layers on the $\mathrm{Mo}_{2} \mathrm{C}$ nanoparticle [20]. However, Kundu el al. observed white glass fiber separator changes to dark blue after several discharge-charge cycles, so they concluded the low charge potential of $\mathrm{Mo}_{2} \mathrm{C}$ comes from the oxidation of $\mathrm{Li}_{x} \mathrm{MoO}_{3}$ [21]. In this report, we have demonstrated the improved electrochemical performance of the $\mathrm{Li}-\mathrm{O}_{2}$ battery using $\mathrm{Mo}_{2} \mathrm{C} / \mathrm{CNT}$ as promoter, and carried out essential electrochemical techniques, with analytical techniques such as X-ray powder diffraction 
(XRD), scanning electron microscopy (SEM), X-ray photoelectron spectroscopy (XPS), and energy dispersive X-ray spectroscopy (EDS) to investigate the reaction mechanism of $\mathrm{Mo}_{2} \mathrm{C} / \mathrm{CNT}$. Based on the presented data and as an extension for our previous Li- $\mathrm{CO}_{2}$ battery studies, we proposed the mechanism that $\mathrm{Mo}_{2} \mathrm{C} / \mathrm{CNT}$ could efficiently stabilizes the highly reactive $\mathrm{LiO}_{2}$ to generate amorphous $(\mathrm{Li}-\mathrm{O}-\mathrm{O})_{x}-\mathrm{Mo}_{2} \mathrm{C}$ as discharge product, thus preventing the formation of crystalline $\mathrm{Li}_{2} \mathrm{O}_{2}$, which is difficult to decompose and induces high overpotential during charge in $\mathrm{Li}-\mathrm{O}_{2}$ battery. We found that the stabilization of Mo-O bonds could prevent the formation of both crystalline $\mathrm{Li}_{2} \mathrm{O}_{2}$ and $\mathrm{Li}_{2} \mathrm{CO}_{3}$, so to maintain good cycling performance and high round-trip efficiency of $\mathrm{Li}$-air batteries and $\mathrm{Li}-\mathrm{CO}_{2} / \mathrm{O}_{2}$ batteries. These studies may offer insight and guidance of solid promoter design, and provide a feasible method for addressing major technical barriers to practical Li-air batteries.

\section{Experimental Section}

\subsection{Synthesis of $\mathrm{Mo}_{2} \mathrm{C} / \mathrm{CNT}$ composite materials}

Molybdenum carbide $\left(\mathrm{Mo}_{2} \mathrm{C}\right) /$ carbon nanotube $(\mathrm{CNT})$ composite materials were prepared via carbothermic reduction of a mixture of molybdenum trioxide $\left(\mathrm{MoO}_{3}\right)$ and CNTs. In a typical procedure, $\mathrm{MoO}_{3}$ and $\mathrm{CNTs}$ were weighed according to the stoichiometric ratio based on the equation $2 \mathrm{MoO}_{3}+7 \mathrm{C}=\mathrm{Mo}_{2} \mathrm{C}+6 \mathrm{CO}$ and mixed via ball milling for $24 \mathrm{~h}$. The rotation speed was $300 \mathrm{rpm}$ and the ball-to-powder weight ratio was $20: 1$. To protect the materials from oxidation, the milling jar was assembled in glovebox under high purity Ar atmosphere. After that, the mixture was heated at $950{ }^{\circ} \mathrm{C}$ for $1 \mathrm{~h}$ under Ar with a heating rate of $10{ }^{\circ} \mathrm{C} \mathrm{min}^{-1}$.

\subsection{Preparation of batteries in different atmospheres}

$\mathrm{Mo}_{2} \mathrm{C} / \mathrm{CNT}$ (or pure CNT) materials were mixed in N-methyl-2-pyrrolidone (NMP) liquid with a polyvinylidene fluoride binder (PVDF) with a weight ratio of active materials to PVDF of 8:2. The 
slurry was pasted onto carbon paper disks (diameter of $14 \mathrm{~mm}$ ) and dried for 12 hours at $120^{\circ} \mathrm{C}$ under vacuum to remove the residual solvent. The loading of electrodes was $\sim 4 \mathrm{mg}$. Electrochemical tests were carried out using coin cells composed of a lithium metal anode, electrolyte ( $1 \mathrm{M} \mathrm{LiCF}_{3} \mathrm{SO}_{3}$ in tetraethylene glycol dimethyl ether (TEGDME) impregnated into a glass fiber separator (Whatman GF/D microfiber filter paper, $2.7 \mu \mathrm{m}$ pore size)). All cell assembly procedures were carried out in an argon-filled glove box (oxygen and water contents less than 0.1 ppm). $\mathrm{Li}-\mathrm{O}_{2}$ battery tests were carried out in an $\mathrm{O}_{2}$-filled chamber, and $\mathrm{Li}$-air battery tests were carried out in an air-filled chamber with molecular sieves to reduce the moisture of ambient air. Li- $\mathrm{CO}_{2} / \mathrm{O}_{2}$ battery testes were carried out in an $\mathrm{O}_{2} / \mathrm{CO}_{2}$-filled chamber. Cells were left for 3 hours in this chamber for stabilization after filling the chamber with gas, but before testing.

\subsection{Physical characterizations}

Powder X-ray diffraction (XRD) was performed on a GBC MMA XRD $(\lambda=1.54 \AA)$ with the voltage and current kept at $-40 \mathrm{kV}$ and $25 \mathrm{~mA}$, respectively. Scanning electron microscopy (SEM) images were obtained from a JEOL JSM-7500FA field emission SEM, in which the accelerating voltage was set at $5.0 \mathrm{kV}$ and the emission current was $10 \mathrm{~mA}$. Raman spectroscopy was carried out on a Jobin-Yvon Horiba 800 with a $10 \mathrm{~mW}$ helium/neon laser at $632.81 \mathrm{~nm}$ excitation. Transmission electron microscopy (TEM) investigations were performed using a $200 \mathrm{kV} \mathrm{JEOL}$ ARM-200F instrument. Thermogravimetric analysis (TGA) was carried out in air using a Q500 (TA Instruments), with data analysis carried out using the Q Series software V. 2.5.0.255. The temperature range studied was from room temperature to $1000^{\circ} \mathrm{C}$ at the rate of $10{ }^{\circ} \mathrm{C} \mathrm{min}^{-1}$. XPS measurements were performed on a VG Scientific ESCALAB 2201XL instrument configured with $\mathrm{Al} \mathrm{K \alpha} \mathrm{X}$-ray radiation. All spectra were fitted with Gaussian-Lorentzian functions and a Shirleytype background using CasaXPS software. For the analysis of Mo 3d spectra, constraints were 
used on the fitting for component pairs: peak area ratio of $2: 3$ for $3 d_{5 / 2}: 3 d_{3 / 2}$ and a maximum 0.2 $\mathrm{eV}$ difference in full width at half maximum (FWHM). The binding energy values were calibrated using the adventitious $\mathrm{C} 1 \mathrm{~s}$ peak at $284.6 \mathrm{eV}$.

\section{Results and Discussions}

A schematic diagram depicting the preparation of $\mathrm{Mo}_{2} \mathrm{C} / \mathrm{CNT}$ composites is shown in Fig. 1a, and the synthesis procedure at each step was also confirmed by SEM images (Fig. 1b). Bulk $\mathrm{MoO}_{3}$ and CNTs were mixed via ball milling and calcinated. After calcination, the mixture of $\mathrm{MoO}_{3}$ and CNT turned into uniformly distributed $\mathrm{Mo}_{2} \mathrm{C} / \mathrm{CNT}$. $\mathrm{MoO}_{3}$ was reduced by $\mathrm{CNT}$, and bulk $\mathrm{MoO}_{3}$ was transformed into $\mathrm{Mo}_{2} \mathrm{C}$ nanoparticles, but unreacted $\mathrm{CNT}$ still existed and acted as the conductive skeleton for the composites. The final product was investigated by XRD (as shown in Fig. 1c), in which several typical diffraction peaks at 34.4, 38.0, 39.4, 52.1, 61.5, 69.6, and $74.6^{\circ}$ were respectively assigned to the (002), (020), (211), (221), (203), (231), and (223) planes of $\beta$ $\mathrm{Mo}_{2} \mathrm{C}$ (PDF-\# 35-0787), confirming that $\mathrm{MoO}_{3}$ was reduced to $\mathrm{Mo}_{2} \mathrm{C}$ after thermal treatment. Thermogravimetric analysis (TGA) of the as-prepared $\mathrm{Mo}_{2} \mathrm{C} / \mathrm{CNT}$ showed that weight ratio of residual CNT was $5.2 \%$, and the $\mathrm{Mo}_{2} \mathrm{C}$ was determined to be $94.8 \%$ (Supplementary Information, Fig. S1). The high-resolution TEM (HRTEM) image indicates that the particles possess a typical crystalline texture, and the selected area electron diffraction (SAED) pattern of the as-prepared $\mathrm{Mo}_{2} \mathrm{C} / \mathrm{CNT}$ shows (002), (100) rings of $\mathrm{CNT}$ and (002), (100) rings of $\mathrm{Mo}_{2} \mathrm{C}$, confirming the presence of carbon nanotubes and crystalline $\mathrm{Mo}_{2} \mathrm{C}$, which is in accordance with the XRD data (Fig. 1d). TEM images in a highly resolved small area of $\mathrm{Mo}_{2} \mathrm{C} / \mathrm{CNT}$ show uniform distributions of $\mathrm{Mo}_{2} \mathrm{C}$ and carbon nanotubes in both bright field and dark field, and energy dispersive spectroscopy (EDS) elemental mapping images in the same area show uniform distributions of Mo 
and $\mathrm{C}$ elements (Fig. 1e). With all the above data, it was confirmed that $\mathrm{Mo}_{2} \mathrm{C} / \mathrm{CNT}$ was successfully synthesized.

The electrochemical testing was carried out using coin cells composed of a lithium metal anode, a glass fiber separator impregnated with electrolyte $\left(1 \mathrm{M}\right.$ lithium triflate $\left(\mathrm{LiCF}_{3} \mathrm{SO}_{3}\right)$ in tetraethylene glycol dimethyl ether (TEGDME)), and a cathode (loaded with $\mathrm{CNT}$ or $\mathrm{Mo}_{2} \mathrm{C} / \mathrm{CNT}$ on carbon paper). The reaction kinetics of $\mathrm{Mo}_{2} \mathrm{C} / \mathrm{CNT}$ was examined by cyclic voltammetry $(\mathrm{CV})$ under oxygen and nitrogen between $2.0-4.2 \mathrm{~V}\left(\mathrm{vs} . \mathrm{Li} / \mathrm{Li}^{+}\right)$at the scan rate of $0.1 \mathrm{mV} \mathrm{s}^{-1}$. As shown in Fig. 2a, the cathodic peak of $\mathrm{Mo}_{2} \mathrm{C} / \mathrm{CNT}$ starts from $2.7 \mathrm{~V}$ (vs. $\mathrm{Li} / \mathrm{Li}^{+}$), where the oxygen reduction reaction takes place in the cell, while half of the anodic peak starts from $3.3 \mathrm{~V}\left(\mathrm{vs} . \mathrm{Li} / \mathrm{Li}^{+}\right)$ where the deposited product starts to decompose. For comparison, there is no obvious peak under nitrogen, showing that the reaction is derived from the reduction of oxygen. The reversibility of $\mathrm{Mo}_{2} \mathrm{C} / \mathrm{CNT}$ under oxygen was tested at a cut-off capacity of $100 \mu \mathrm{Ah}$ at the current rate of $20 \mu \mathrm{A}$, and the results showed that $\mathrm{Mo}_{2} \mathrm{C} / \mathrm{CNT}$ exhibits a remarkably low charging potential of $3.35 \mathrm{~V}$, after 40 discharge-charge cycles (Fig. 2b). On the contrary, the current contributed by CNTs to the cathodic peak is relatively high, indicating that CNT has larger surface area and more active sites for oxygen reduction; but the current contributed by CNT to the anodic peak is low, indicating that the decomposition of discharge products cannot proceed well in this voltage range (Fig. 2c). In full discharge-charge tests, the potential gap for CNTs between discharge and charge is $1.67 \mathrm{~V}$, but for $\mathrm{Mo}_{2} \mathrm{C} / \mathrm{CNT}$, it is only $0.76 \mathrm{~V}$, showing that the introduction of $\mathrm{Mo}_{2} \mathrm{C} / \mathrm{CNT}$ can significantly reduce charge overpotentials (Fig. 2d).

To investigate the cause of low charge voltage plateau, continuous galvanostatic dischargecharge was carried out in switched $\mathrm{N}_{2} / \mathrm{O}_{2}$ atmosphere (Supporting information, Fig. S2). In first step, after purging with oxygen, the cell using $\mathrm{Mo}_{2} \mathrm{C} / \mathrm{CNT}$ as electrode succeeded in discharging 
and charging under oxygen for 20 hours. However, the cell failed in discharging when atmosphere was switched to $\mathrm{N}_{2}$ in second step. In third step, the cell could resume discharging and charging for another 20 hours when atmosphere was switched to $\mathrm{O}_{2}$. This study initially confirmed that the low charge voltage plateau is related to oxygen evolution reaction, not related to de-intercalation of lithium compound in same voltage range [22]. In a study performed by Kundu et al, they explained that the low charge voltage plateau derives from oxidation of $\mathrm{Li}_{\mathrm{x}} \mathrm{MoO}_{3}$, and formation of $\mathrm{Li}_{x} \mathrm{MoO}_{3}$ gives a blue colour on glassfiber [21]. However, we found that such a deep blue colour on glassfiber could only be observed when the cell was overcharged under nitrogen. The glassfiber was clean after discharge and charge under oxygen, indicating the good reversibility can be maintained if voltage was limited below 3.8 V (Supporting information, Fig. S3). Based on this, we ascribed the deep blue colour to instability of $\mathrm{Mo}_{2} \mathrm{C}$ at high voltage in place of the formation of $\mathrm{Li}_{\mathrm{x}} \mathrm{MoO}_{3}$, and ascertained that the charge voltage should be limited below $3.8 \mathrm{~V}$ to avoid the reaction of $\mathrm{Mo}_{2} \mathrm{C}$.

In addition, $\mathrm{Mo}_{2} \mathrm{C} / \mathrm{CNT}$ electrodes at different stages were prepared and analyzed to obtain insight into the structural origins of the observed low charge potential and improved cycling performance. In a typical procedure, we assembled two $\mathrm{Li}-\mathrm{O}_{2}$ cells with $\mathrm{Mo}_{2} \mathrm{C} / \mathrm{CNT}$ as cathode, one was discharged to $2.0 \mathrm{~V}$ at the current rate of $20 \mu \mathrm{A}$, and after disassembly, we obtained the discharged electrode; the other was discharged to $2.0 \mathrm{~V}$ first, then charged to $3.8 \mathrm{~V}$ at the current rate of $20 \mu \mathrm{A}$, and after disassembly, we obtained the charged electrode. The pristine electrode is a freshly prepared $\mathrm{Mo}_{2} \mathrm{C} / \mathrm{CNT}$ electrode without any previous electrochemical testing. The voltage profile for electrode preparation is shown in Fig. 3a, and the pristine electrode, discharged electrode, and charged electrode were positioned at points A, B, and C in the voltage profile. We first used XRD to determine the structural changes of $\mathrm{Mo}_{2} \mathrm{C} / \mathrm{CNT}$ electrode during discharge- 
charge process. As shown in Fig. 3b, the XRD patterns show peaks corresponding to $\mathrm{Mo}_{2} \mathrm{C}$ and graphite from carbon paper in the pristine, discharged, and recharged $\mathrm{Mo}_{2} \mathrm{C} / \mathrm{CNT}$ cathodes, but there is no peak showing the presence of crystalline $\mathrm{Li}_{2} \mathrm{O}_{2}$ in the discharged $\mathrm{Mo}_{2} \mathrm{C} / \mathrm{CNT}$ electrode, indicating that an amorphous discharge product was formed during the discharge process. SEM was then used to confirm the existence of the amorphous discharge product, as shown in Fig. 3ce. Uniformly dispersed $\mathrm{Mo}_{2} \mathrm{C}$ and $\mathrm{CNT}$ were observed in the pristine $\mathrm{Mo}_{2} \mathrm{C} / \mathrm{CNT}$ electrode before discharge; after discharge, there is a thin film on the surface of the $\mathrm{Mo}_{2} \mathrm{C} / \mathrm{CNT}$ electrode, and then this thin film disappears after the electrode is fully charged.

To investigate this amorphous thin film on the surface of the $\mathrm{Mo}_{2} \mathrm{C} / \mathrm{CNT}$ electrode, X-ray photoelectron spectroscopy (XPS) of Mo 3d was carried out and fitted with the contributions of $\mathrm{Mo}^{2+}, \mathrm{Mo}^{3+}, \mathrm{Mo}^{5+}$, or $\mathrm{Mo}^{6+}$ on the surfaces of the $\mathrm{Mo}_{2} \mathrm{C} / \mathrm{CNT}$ electrodes (fitting details shown in the Supporting Information, Table S1). For the pristine $\mathrm{Mo}_{2} \mathrm{C} / \mathrm{CNT}$ electrode, the low oxidation states of $\mathrm{Mo}^{2+}$ and $\mathrm{Mo}^{3+}$ can be explained for the existence of both Mo-Mo and Mo-C bonds, and the high oxidation states of $\mathrm{Mo}^{5+}$ and $\mathrm{Mo}^{6+}$ can be explained for the contaminated surface of molybdenum oxides such as $\mathrm{MoO}_{2}$ and $\mathrm{MoO}_{3}$ when the $\mathrm{Mo}_{2} \mathrm{C} / \mathrm{CNT}$ was exposed in air (Fig. 3f). After discharge in oxygen, peaks for $\mathrm{Mo}^{2+}$ and $\mathrm{Mo}^{3+}$ disappeared while peaks for $\mathrm{Mo}^{5+}$ and $\mathrm{Mo}^{6+}$ increased, indicating the oxidation of $\mathrm{Mo}_{2} \mathrm{C}$ surface with the formation of Mo-O bonds (Fig. 3g). After recharge in oxygen, peaks for $\mathrm{Mo}^{2+}, \mathrm{Mo}^{3+}$ recovered while peaks for $\mathrm{Mo}^{5+}$ and $\mathrm{Mo}^{6+}$ decreased to pristine state, indicating the reduction of oxidized $\mathrm{Mo}_{2} \mathrm{C}$ surface with the cleavage of Mo-O bonds (Fig. 3h). Based on these results, the reversible formation and cleavage of Mo-O bonds may be responsible for the low charge overpotentials and high cyclability.

To corroborate the reversible formation and decomposition of the oxygen reduction product, we simultaneously characterized these different stages of $\mathrm{Mo}_{2} \mathrm{C} / \mathrm{CNT}$ electrodes by survey spectra of 
XPS and EDS mapping. The survey spectra of XPS clearly reflect the change of oxygen peaks, showing deposition of oxygen species in discharge and releasing of oxygen species in charge (Supporting Information, Fig. S4). In agreement with the XPS results, the EDS element mapping clearly shows the change of intensity for elemental oxygen, indicating that reduction species of oxygen deposited on the surface of the $\mathrm{Mo}_{2} \mathrm{C} / \mathrm{CNT}$ electrode in discharge, and released from the surface of the $\mathrm{Mo}_{2} \mathrm{C} / \mathrm{CNT}$ electrode in charge (Supporting Information, Fig. S5). Moreover, when these electrodes were exposed to air for several days, crystalline $\mathrm{Li}_{2} \mathrm{MoO}_{4}$ was detected from discharged electrode only (Supporting Information, Fig. S6). This finding shows that amorphous discharge product has similar chemical property to mixed $\mathrm{LiOH} \cdot \mathrm{H}_{2} \mathrm{O}$ and $\mathrm{MoO}_{3}$ at room temperature [23], confirming the existence of Mo-O bonds in amorphous discharge product.

As mentioned above, $\mathrm{Mo}_{2} \mathrm{C}$ does not operate as an electrocatalyst like $\mathrm{Pt} / \mathrm{C}$ in the aqueous oxygen reduction reaction. Neither does it operate as an OER catalyst, decomposing crystalline $\mathrm{Li}_{2} \mathrm{O}_{2}$, which can normally be characterized by diffraction methods. Instead, it operates by a different mechanism that changes the pathway of $\mathrm{O}_{2}$ reduction to insulating $\mathrm{Li}_{2} \mathrm{O}_{2}$, but stabilizes the reactive $\mathrm{LiO}_{2}$ intermediate to form an amorphous product through solid-state reaction. In the absence of $\mathrm{Mo}_{2} \mathrm{C}$, reduction of $\mathrm{O}_{2}$ to $\mathrm{Li}_{2} \mathrm{O}_{2}$ proceeds via the $\mathrm{LiO}_{2}$ intermediate on the surface of CNT electrode during discharge [24]. Equation (1) shows the oxygen undergoes one-electron reduction to form $\mathrm{O}_{2}{ }^{-}$, then combines with a $\mathrm{Li}^{+}$ion to form $\mathrm{LiO}_{2}$ in solution or surface adsorbed $\mathrm{LiO}_{2}$ intermediate. Equation (2) and (3) show $\mathrm{LiO}_{2}$ as a transient intermediate is not stable at room temperature and quickly converts to $\mathrm{Li}_{2} \mathrm{O}_{2}$ via a disproportionation reaction or an additional $\mathrm{Li}^{+}-$ induced charge transfer. As a wide band-gap insulator and insoluble species, bulk $\mathrm{Li}_{2} \mathrm{O}_{2}$ is difficult to decompose below $4.0 \mathrm{~V}$. Moreover, this highly oxidized $\mathrm{LiO}_{2}$ intermediate could also induce the oxidization of the carbon surface to $\mathrm{Li}_{2} \mathrm{CO}_{3}$, and even one monolayer of $\mathrm{Li}_{2} \mathrm{CO}_{3}$ at the $\mathrm{C}-\mathrm{Li}_{2} \mathrm{O}_{2}$ 
interface can cause a $\sim 10-100$-fold decrease in the exchange current density due to interfacial resistance to charge transport [25]. Unlike $\mathrm{NaO}_{2}$ in $\mathrm{Na}-\mathrm{O}_{2}$ batteries, which generates and stably exists in the discharge stage and decomposes at low voltage plateau in the charge stage, the $\mathrm{LiO}_{2}$ converts to $\mathrm{Li}_{2} \mathrm{O}_{2}$, which decomposes at high voltage above $4.0 \mathrm{~V}$ in the charge stage [26].

$$
\begin{gathered}
\mathrm{O}_{2}+\mathrm{Li}^{+}+\mathrm{e}^{-} \rightarrow \mathrm{LiO}_{2} \\
2 \mathrm{LiO}_{2} \rightarrow \mathrm{Li}_{2} \mathrm{O}_{2}+\mathrm{O}_{2} \\
\mathrm{LiO}_{2}+\mathrm{Li}^{+}+\mathrm{e}^{-} \rightarrow \mathrm{Li}_{2} \mathrm{O}_{2}
\end{gathered}
$$

To capture and stabilize $\mathrm{LiO}_{2}$ species could prevent them from surface-mediated disproportionation and further reduction to $\mathrm{Li}_{2} \mathrm{O}_{2}$. It is reported that Glassy carbon with surface defects, oxidized carbon and Ir-based catalyst were proved to stabilize $\mathrm{Li}_{\mathrm{x}} \mathrm{O}_{2} / \mathrm{LiO}_{2}$ species in discharge and facilely decompose in subsequent charge $[9,27,28]$. Unsaturated coordination of Mo states on the $\mathrm{Mo}_{2} \mathrm{C}$ surface is thought to be responsible for its high catalytic activity towards dehydrogenation and electrochemical hydrogen evolution [12, 29]. Meanwhile, this metal center was expected to have a strong affinity for oxygen, thus favoring a surface mediated ORR process or $\mathrm{CO}_{2}$ reduction process [19]. Moreover, the active surface is expected to be highly electrically conductive, owing to the well-known metallic properties of the underlying $\mathrm{Mo}_{2} \mathrm{C}$. Therefore, we speculate that $\mathrm{Mo}_{2} \mathrm{C}$ could stabilize the active $\mathrm{LiO}_{2}$ intermediate to generate amorphous ( $\mathrm{Li}-\mathrm{O}-$ $\mathrm{O})_{x}-\mathrm{Mo}_{2} \mathrm{C}$ via the formation of Mo-O bonds, preventing further reduction and disproportionation of $\mathrm{LiO}_{2}$ intermediate to crystalline $\mathrm{Li}_{2} \mathrm{O}_{2}$ in Equation (4). The facile decomposition of amorphous (Li-O-O) $)_{x}-\mathrm{Mo}_{2} \mathrm{C}$ in Equation (5), instead of difficult decomposition of crystalline $\mathrm{Li}_{2} \mathrm{O}_{2}$ may be responsible for the reduced charging overpotentials observed in our results.

$$
\begin{gathered}
x \mathrm{LiO}_{2}+\mathrm{Mo}_{2} \mathrm{C} \rightarrow(\mathrm{Li}-\mathrm{O}-\mathrm{O})_{x}-\mathrm{Mo}_{2} \mathrm{C} \\
(\mathrm{Li}-\mathrm{O}-\mathrm{O})_{x}-\mathrm{Mo}_{2} \mathrm{C} \rightarrow \mathrm{Mo}_{2} \mathrm{C}+x \mathrm{O}_{2}+x \mathrm{Li}^{+}+x \mathrm{e}^{-}
\end{gathered}
$$


This is also confirmed by the electrochemical behavior of $\mathrm{Mo}_{2} \mathrm{C} / \mathrm{CNT}$ in both $\mathrm{O}_{2}$ and $\mathrm{CO}_{2}$ in full discharge-charge testing (Fig. 4a). Different discharge voltage plateaus showed different reduction voltages based on the different electrochemical reduction of $\mathrm{O}_{2}$ or $\mathrm{CO}_{2}$. When the $\mathrm{Mo}$ in $\mathrm{Mo}_{2} \mathrm{C}$ completes the coordination with $\mathrm{O}$, regardless of whether the unsaturated Mo bonds with $\mathrm{O}$ from $\mathrm{O}_{2}$ or $\mathrm{CO}_{2}$, the Mo-O bond dissociation energy is the same, so the charge voltage plateau remains the same in both $\mathrm{O}_{2}$ and $\mathrm{CO}_{2}$ atmospheres. We also compared CNT and $\mathrm{Mo}_{2} \mathrm{C} / \mathrm{CNT}$ in cut-off capacity discharge-charge, and the $\mathrm{Mo}_{2} \mathrm{C} / \mathrm{CNT}$ prominently reduced the charge overpotential and improved the round-trip efficiency in both $\mathrm{O}_{2}$ and $\mathrm{CO}_{2}(\mathbf{F i g} . \mathbf{4 b})$. At this point, we speculate that the formation of Mo-O bonds could stabilize the reduction intermediate with oxygen-containing groups. As shown in Fig. 4c, the reversible formation and decomposition of the amorphous discharge product in both $\mathrm{O}_{2}$ and $\mathrm{CO}_{2}$ via the formation and cleavage of Mo-O bonds in $\mathrm{Li}-\mathrm{O}_{2}$ batteries and $\mathrm{Li}-\mathrm{CO}_{2}$ batteries, make $\mathrm{Mo}_{2} \mathrm{C} / \mathrm{CNT}$ a potential efficient and $\mathrm{CO}_{2}$-robust promoter in practical Li-air batteries.

Finally, we investigated the cycle stability of practical Li-air batteries using $\mathrm{Mo}_{2} \mathrm{C} / \mathrm{CNT}$ as electrode. After 5 discharge-charge cycling between the voltage of $2.0 \mathrm{~V}$ and $3.8 \mathrm{~V}$, the capacity of practical Li-air battery using $\mathrm{Mo}_{2} \mathrm{C} / \mathrm{CNT}$ still maintain more than $80 \%$, with high energy efficiency of $80 \%$ (Fig. 5a). In contrast, the capacity of practical Li-air battery using CNT shows fast fading to only $40 \%$ after 5 discharge-charge cycling, with the charge voltage extend to $4.6 \mathrm{~V}$ (Fig. 5b). We also carried out cut-off capacity discharge-charge testing, and it was found that the $\mathrm{Mo}_{2} \mathrm{C} / \mathrm{CNT}$ can reversibly discharge and charge for 40 cycles (Fig. 5c) with high round-trip efficiency, showing good cycling performance even in presence of a trivial amount of $\mathrm{CO}_{2}$.

To investigate the influence of $\mathrm{CO}_{2}$, we increased the ratio of $\mathrm{CO}_{2}$ by filling a mixture of $\mathrm{CO}_{2}$ and $\mathrm{O}_{2}$ which contained $50 \% \mathrm{CO}_{2}$ instead of ambient air into the chamber. The cell using 
$\mathrm{Mo}_{2} \mathrm{C} / \mathrm{CNT}$ can still reversibly discharge and charge for 40 cycles with round-trip efficiency of 80 $\%$ (Fig. 5d). Based on the low charge voltage plateau of $\sim 3.4 \mathrm{~V}$ in both Li-air battery and Li$\mathrm{CO}_{2} / \mathrm{O}_{2}$ battery, we exclude the formation of crystal $\mathrm{Li}_{2} \mathrm{O}_{2}$ and $\mathrm{Li}_{2} \mathrm{CO}_{3}$, which do not decompose until high voltage $\left(>4 \mathrm{~V}\right.$ vs. $\left.\mathrm{Li} / \mathrm{Li}^{+}\right)$. At this point, our proposed mechanism was confirmed that the intermediate species from reduction of $\mathrm{O}_{2}$ and $\mathrm{CO}_{2}$ could be appropriately stabilized by $\mathrm{Mo}_{2} \mathrm{C} / \mathrm{CNT}$ promoter via the formation of Mo-O bonds. Since amorphous (Li-O-O) $)_{x}-\mathrm{Mo}_{2} \mathrm{C}$ and (Li-O-C-O) $)_{x}-\mathrm{Mo}_{2} \mathrm{C}$ generate instead of crystalline $\mathrm{Li}_{2} \mathrm{O}_{2}$ and $\mathrm{Li}_{2} \mathrm{CO}_{3}$ during discharge process, the subsequent decomposition could remain low charge voltage.

\section{Conclusion}

In summary, we have exploited $\mathrm{Mo}_{2} \mathrm{C} / \mathrm{CNT}$ as a promoter for practical $\mathrm{Li}$-air batteries with high round-trip efficiency and good cycling performance. As a bifunctional promoter in both $\mathrm{O}_{2}$ and $\mathrm{CO}_{2}$ atmospheres, $\mathrm{Mo}_{2} \mathrm{C} / \mathrm{CNT}$ can efficiently stabilize both intermediate species from reduction of $\mathrm{O}_{2}$ and $\mathrm{CO}_{2}$ to generate amorphous ( $\left.\mathrm{Li}-\mathrm{O}-\mathrm{O}\right)_{x}-\mathrm{Mo}_{2} \mathrm{C}$ and ( $\left.\mathrm{Li}-\mathrm{O}-\mathrm{C}-\mathrm{O}\right)_{x}-\mathrm{Mo}_{2} \mathrm{C}$ discharge product, respectively, preventing the formation of crystalline $\mathrm{Li}_{2} \mathrm{O}_{2}$ and $\mathrm{Li}_{2} \mathrm{CO}_{3}$. Correspondingly, the charge potential can be significantly reduced owing to decomposition of the amorphous discharge products, instead of the decomposition of crystalline $\mathrm{Li}_{2} \mathrm{O}_{2}$ and $\mathrm{Li}_{2} \mathrm{CO}_{3}$. Meanwhile, we predict that this promoter has the potential to pave the way towards a commercially achievable Li-air battery in an open system, not requiring a sealed oxygen tank. Our findings clearly identify the critical role of metal-oxygen bonds in Li-gas batteries, suggesting that the low valence metal in metal compound provides a suitable environment for surface stabilization of $\mathrm{O}_{2}$ and $\mathrm{CO}_{2}$ reduction product. This work has a broader implication to guide rational design strategies for other promoters such as metal carbides, metal sulfide which metal centers in the unsaturated coordination state. More importantly, the understanding of cationic redox and anionic redox further inspires us to 
explore new battery systems with longer life and higher energy density such as anion redox metal compound/ $\mathrm{LiO}_{\mathrm{x}}$ system.

\section{Acknowledgements}

Financial support from Australian Research Council (ARC) Discovery Projects (DP140100401 and DP170102267) is greatly appreciated. The authors also are grateful for the use of the facilities in the UOW Electron Microscopy Center. Many thanks also go to Dr. Tania Silver for critical reading of the manuscript. The authors would like to thank the Australian National Fabrication Facility (ANFF) for equipment access.

\section{Appendix A. Supplementary data}

Supplementary data associated with this article can be found in the online version.

\section{References}

[1] J. Lu, L. Li, J. B. Park, Y. K. Sun, F. Wu, K. Amine, Aprotic and aqueous Li-O ${ }_{2}$ batteries, Chem. Rev. 114 (2014) 5611-5640.

[2] P. G. Bruce, S. A. Freunberger, L. J. Hardwick, J. M. Tarascon, Li-O 2 and Li-S batteries with high energy storage, Nat. Mater. 11 (2011) 19-29.

[3] H.-G. Jung, Y. S. Jeong, J.-B. Park, Y.-K. Sun, B. Scrosati, Y. J. Lee, Ruthenium-based electrocatalysts supported on reduced graphene oxide for lithium-air batteries, ACS Nano 7 (2013) 3532-3539.

[4] M. M. Ottakam Thotiyl, S. A. Freunberger, Z. Peng, Y. Chen, Z. Liu, P. G. Bruce, A stable cathode for the aprotic Li-O 2 battery, Nat. Mater. 12 (2013) 1050-1056.

[5] B. Sun, X. Huang, S. Chen, P. Munroe, G. Wang, Porous graphene nanoarchitectures: an efficient catalyst for low charge-overpotential, long life, and high capacity lithium-oxygen batteries, Nano Lett. 14 (2014) 3145-3152. 
[6] K. P. C. Yao, M. Risch, S. Y. Sayed, Y.-L. Lee, J. R. Harding, A. Grimaud, N. Pour, Z. Xu, J. Zhou, A. Mansour, F. Bardé, Y Shao-Horn, Solid-state activation of $\mathrm{Li}_{2} \mathrm{O}_{2}$ oxidation kinetics and implications for $\mathrm{Li}-\mathrm{O}_{2}$ batteries, Energy Environ. Sci. 8 (2015) 2417-2426.

[7] B. D. McCloskey, D. Addison, A viewpoint on heterogeneous electrocatalysis and redox mediation in nonaqueous $\mathrm{Li}_{-} \mathrm{O}_{2}$ batteries, ACS Catal. 7 (2017) 772-778.

[8] Y. Wang, Z. Liang, Q. Zou, G. Cong, Y.-C. Lu, Mechanistic insights into catalyst-assisted nonaqueous oxygen evolution reaction in lithium-oxygen batteries, J. Phys. Chem. C 120 (2016) 6459-6466.

[9] J. Lu, Y. J. Lee, X. Luo, K. C. Lau, M. Asadi, H. H. Wang, S. Brombosz, J. Wen, D. Zhai, Z. Chen, D. J. Miller, Y. S. Jeong, J. B. Park, Z. Z. Fang, B. Kumar, A. Salehi-Khojin, Y. K. Sun, L. A. Curtiss, K. Amine, A lithium-oxygen battery based on lithium superoxide, Nature 529 (2016) 377-382.

[10]L. Trahey, N. K. Karan, M. K. Y. Chan, J. Lu, Y. Ren, J. Greeley, M. Balasubramanian, A. K. Burrell, L. A. Curtiss, M. M. Thackeray, Synthesis, characterization, and structural modeling of high-capacity, dual functioning $\mathrm{MnO}_{2}$ electrode/electrocatalysts for $\mathrm{Li}^{-} \mathrm{O}_{2}$ cells, Adv. Energy Mater. 3 (2013) 75-84.

[11]J. Zhang, W. Xu, X. Li, W. Liu, Air dehydration membranes for nonaqueous lithium-air batteries. J. Electrochem. Soc. 157 (2010) A940-A946.

[12]H. K. Lim, H. D. Lim, K. Y. Park, D. H. Seo, H. Gwon, J. Hong, W. A. Goddard, H. Kim, K. Kang, Toward a lithium-"air" battery: the effect of $\mathrm{CO}_{2}$ on the chemistry of a lithium-oxygen cell. J. Am. Chem. Soc. 135 (2013) 9733-9742.

[13]Z. Zhang, Q. Zhang, Y. Chen, J. Bao, X. Zhou, Z. Xie, J. Wei, Z. Zhou, The first introduction of graphene to rechargeable Li- $\mathrm{CO}_{2}$ batteries. Angew. Chem. Int. Ed. 54 (2015) 6550-6553. 
[14]X. Hu, Z. Li, J. Chen, Flexible Li-CO $\mathrm{CO}_{2}$ batteries with liquid-free electrolyte. Angew. Chem. Int. Ed. 56 (2017) 5785-5789.

[15]X. Zhang, X.-G. Wang, Z. Xie, Z. Zhou, Recent progress in rechargeable alkali metal-air batteries. Green Energy Environ. 1 (2016) 4-17.

[16]Z. Xie, X. Zhang, Z. Zhang, Z. Zhou, Metal- $\mathrm{CO}_{2}$ batteries on the road: $\mathrm{CO}_{2}$ from contamination gas to energy source. Adv. Mater. 29 (2017) 1605891.

[17]X.-G. Wang, C. Wang, Z. Xie, X. Zhang, Y. Chen, D. Wu, Z. Zhou, Improving electrochemical performances of rechargeable $\mathrm{Li}-\mathrm{CO}_{2}$ batteries with an electrolyte redox mediator. ChemElectroChem (2017) DOI: 10.1002/celc.201700539

[18] S. Xu, S. K. Das, L. A. Archer, The Li- $\mathrm{CO}_{2}$ battery: a novel method for $\mathrm{CO}_{2}$ capture and utilization. RSC Adv. 3 (2013) 6656-6660.

[19] Y. Hou, J. Wang, L. Liu, Y. Liu, S. Chou, D. Shi, H. Liu, Y. Wu, W. Zhang, J. Chen, $\mathrm{Mo}_{2} \mathrm{C} / \mathrm{CNT}$ : an efficient catalyst for rechargeable $\mathrm{Li}_{-} \mathrm{CO}_{2}$ batteries. Adv. Funct. Mater. (2017) 1700564.

[20] W.-J. Kwak, K. C. Lau, C.-D. Shin, K. Amine, L. Curtiss, Y.-K. Sun, A $\mathrm{Mo}_{2} \mathrm{C} /$ carbon nanotube composite cathode for lithium-oxygen batteries with high energy efficiency and long cycle life. ACS Nano. 9 (2015) 4129-4137.

[21]D. Kundu, R. Black, B. Adams, K. Harrison, K. Zavadil, L. F. Nazar, Nanostructured metal carbides for aprotic $\mathrm{Li}-\mathrm{O}_{2}$ batteries: new insights into interfacial reactions and cathode stability. J. Phys. Chem. Lett. 6 (2015) 2252-2258.

[22] J. Zheng, Y. Hou, Y. Duan, X. Song, Y. Wei, T. Liu, J. Hu, H. Guo, Z. Zhuo, L. Liu, Z. Chang, X. Wang, D. Zherebetskyy, Y. Fang, Y. Lin, K. Xu, L. W. Wang, Y. Wu, F. Pan, Janus solid- 
liquid interface enabling ultrahigh charging and discharging rate for advanced lithium-ion batteries. Nano Lett. 15 (2015) 6102-6109.

[23]T. W. S. Yip, E. J. Cussen, C. Wilsonb, Spontaneous formation of crystalline lithium molybdate from solid reagents at room temperature. Dalton Trans. 39 (2010) 411-417.

[24]B. D. McCloskey, R. Scheffler, A. Speidel, G. Girishkumar, A. C. Luntz, On the mechanism of nonaqueous $\mathrm{Li}_{-} \mathrm{O}_{2}$ electrochemistry on $\mathrm{C}$ and its kinetic overpotentials: some implications for Li-air batteries. J. Phys. Chem. C 116 (2012) 23897-23905.

[25]B. D. McCloskey, A. Speidel, R. Scheffler, D. C. Miller, V. Viswanathan, J. Hummelshøj, J. Nørskov, A. C. Luntz, Twin problems of interfacial carbonate formation in nonaqueous $\mathrm{Li}-\mathrm{O}_{2}$ batteries. J. Phys. Chem. Lett. 3 (2012) 997-1001.

[26]B. D. McCloskey, J. M. Garcia, A. C. Luntz, Chemical and electrochemical differences in nonaqueous $\mathrm{Li}_{-} \mathrm{O}_{2}$ and $\mathrm{Na}-\mathrm{O}_{2}$ batteries. J. Phys. Chem. Lett. 5 (2014) 1230-1235.

[27]R. A. Wong, A. Dutta, C. Yang, K. Yamanaka, T. Ohta, A. Nakao, K. Waki, H. R. Byon, Structually tuning $\mathrm{Li}_{2} \mathrm{O}_{2}$ by controlling the surface properties of carbon electrodes: implications for $\mathrm{Li}^{-} \mathrm{O}_{2}$ batteries. Chem. Mater. 28 (2016) 8006-8015

[28]A. Belova, D. G. Kwabi, L. V. Yashina, Y. Shao-Horn, D. M. Itkis, Mechanism of oxygen reduction in aprotic Li-air batteries: the role of carbon electrode surface structure. J. Phys. Chem. C 121(2017) 1569-1577

[29]H. Ren, W. Yu, M. Salciccioli, Y. Chen, Y. Huang, K. Xiong, D. G. Vlachos, J. G. Chen, Selective hydrodeoxygenation of biomass-derived oxygenates to unsaturated hydrocarbons using molybdenum carbide catalysts. ChemSusChem 6 (2013) 798-801. 
a)
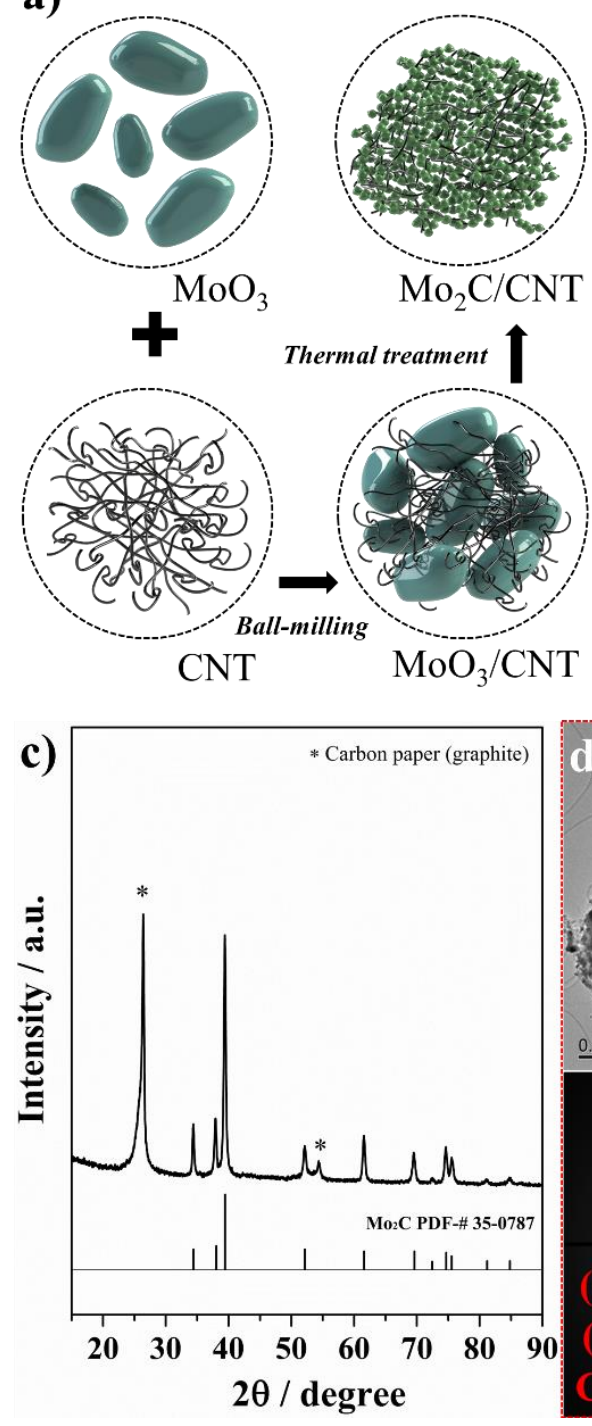

b)

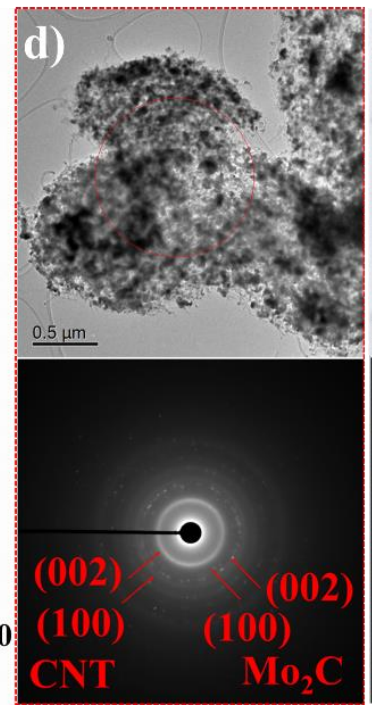

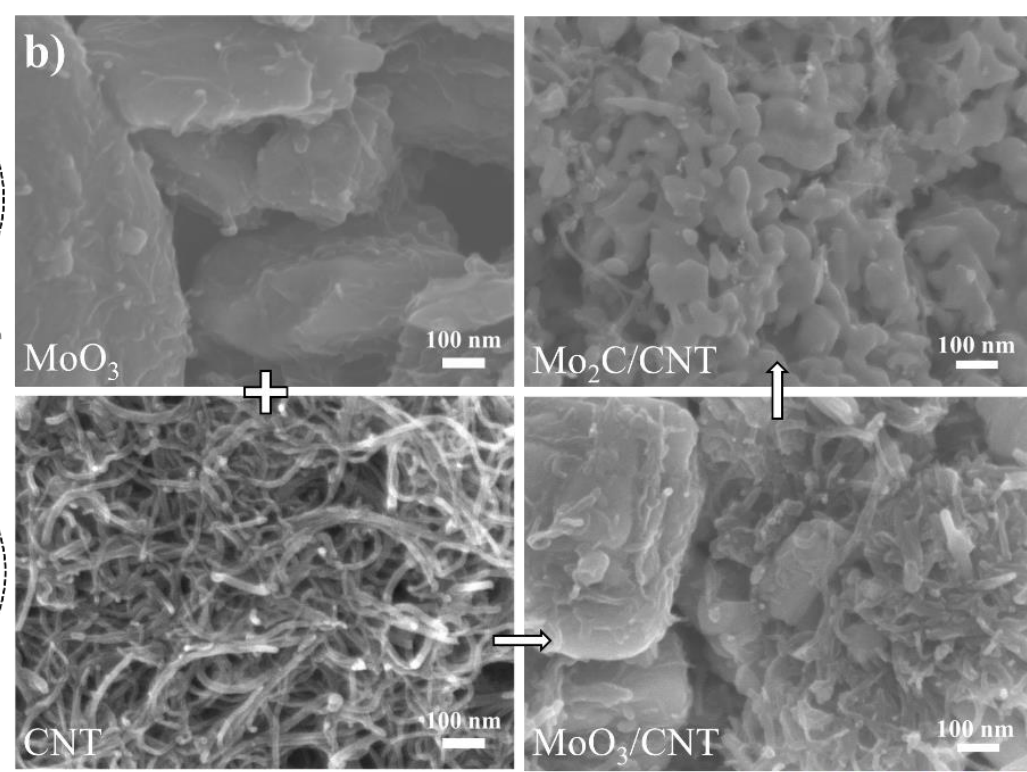

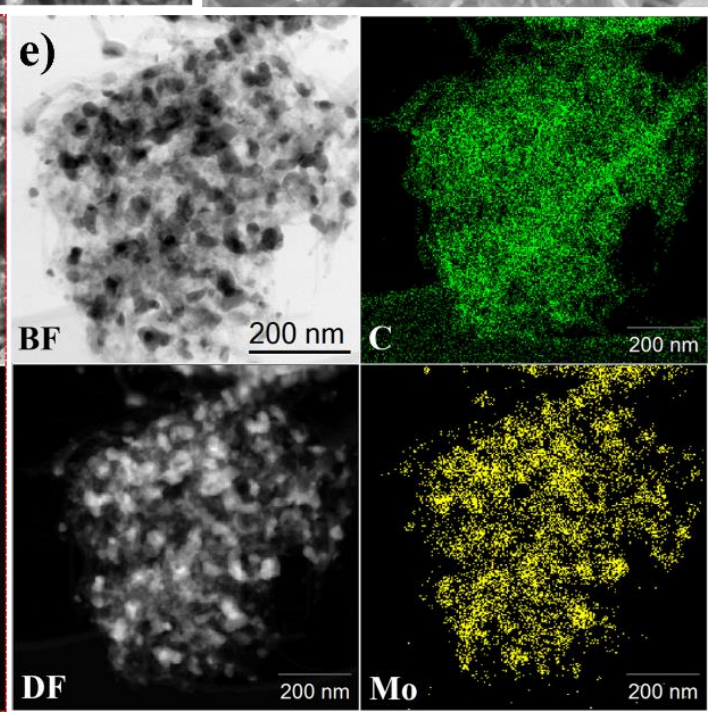

Fig. 1. a) Schematic illustrations depicting the synthesis procedure for $\mathrm{Mo}_{2} \mathrm{C} / \mathrm{CNT}$ composite materials; b) SEM images of the synthesis procedure at each step; c) XRD pattern of $\mathrm{Mo}_{2} \mathrm{C} / \mathrm{CNT}$ composites; d) transmission electron microscope (TEM) image with SAED pattern of the asprepared $\mathrm{Mo}_{2} \mathrm{C} / \mathrm{CNT}$; e) The corresponding bright field (BF) image, dark field (DF) image, and element mapping of $\mathrm{Mo}_{2} \mathrm{C} / \mathrm{CNT}$ composite (green for $\mathrm{C}$, and yellow for $\mathrm{Mo}$ ) 

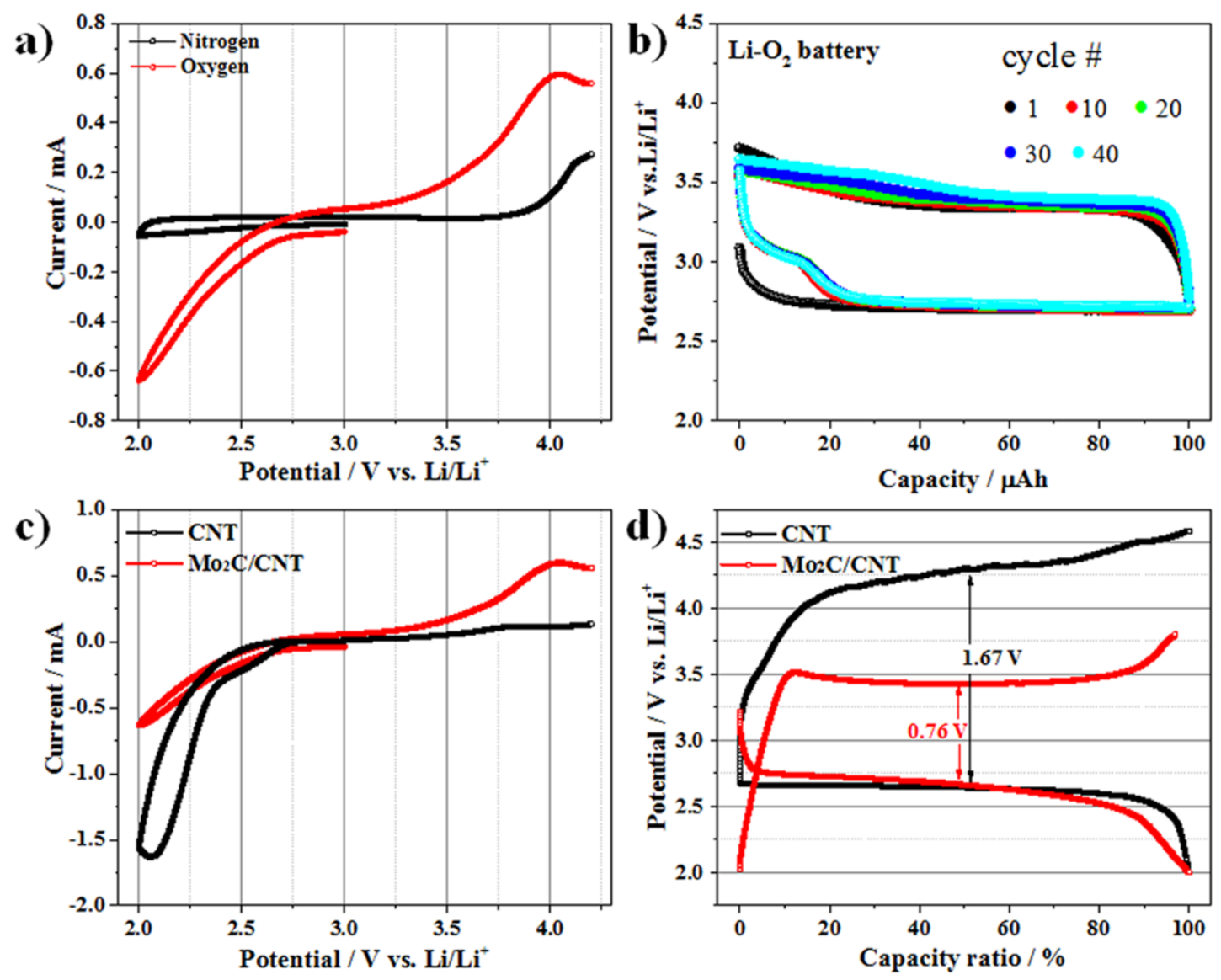

Fig. 2. Electrochemical tests: a) Cyclic voltammograms of $\mathrm{Mo}_{2} \mathrm{C} / \mathrm{CNT}$ in oxygen and nitrogen; b) Galvanostatic discharge-charge voltage profiles of $\mathrm{Mo}_{2} \mathrm{C} / \mathrm{CNT}$ in oxygen for selected cycles; c) Cyclic voltammograms of $\mathrm{Mo}_{2} \mathrm{C} / \mathrm{CNT}$ and CNT in oxygen; d) Voltage profiles of the CNT and $\mathrm{Mo}_{2} \mathrm{C} / \mathrm{CNT}$ cathodes. 

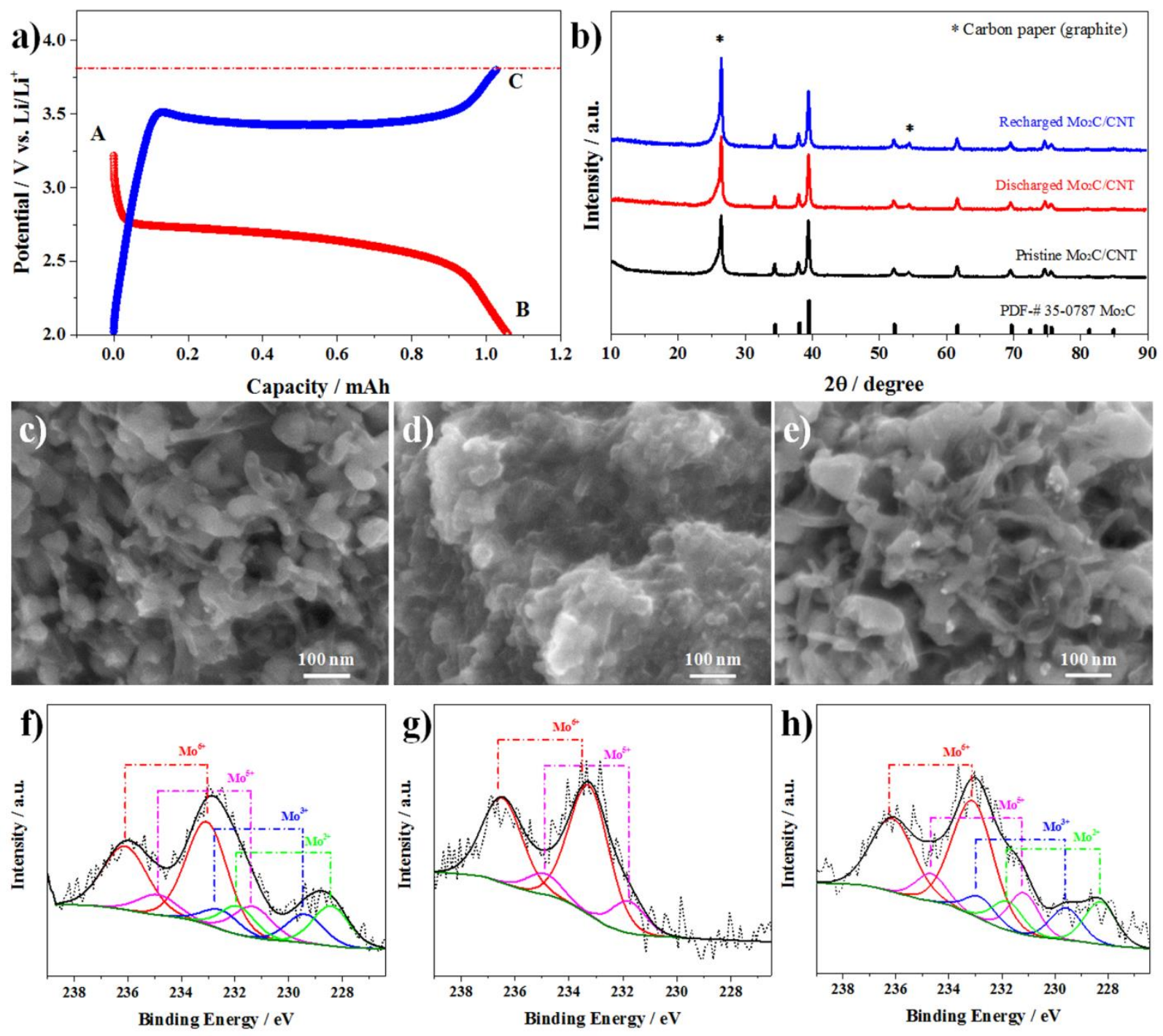

Fig. 3. a) Full discharge and charge cycle of $\mathrm{Mo}_{2} \mathrm{C} / \mathrm{CNT}$ in a $\mathrm{Li}^{-\mathrm{O}_{2}}$ battery (pristine electrode at position A, fully discharged electrode at position B, and fully recharged electrode at position C). b) XRD images of $\mathrm{Mo}_{2} \mathrm{C} / \mathrm{CNT}$ electrode at different stages (pristine, discharged, recharged). c-e) SEM images of $\mathrm{Mo}_{2} \mathrm{C} / \mathrm{CNT}$ of $\mathrm{Mo}_{2} \mathrm{C} / \mathrm{CNT}$ electrode at different stages (pristine, discharged, recharged). f-h) XPS spectra showing Mo 3d peaks of $\mathrm{Mo}_{2} \mathrm{C} / \mathrm{CNT}$ electrode at different stages (pristine, discharged, recharged). 

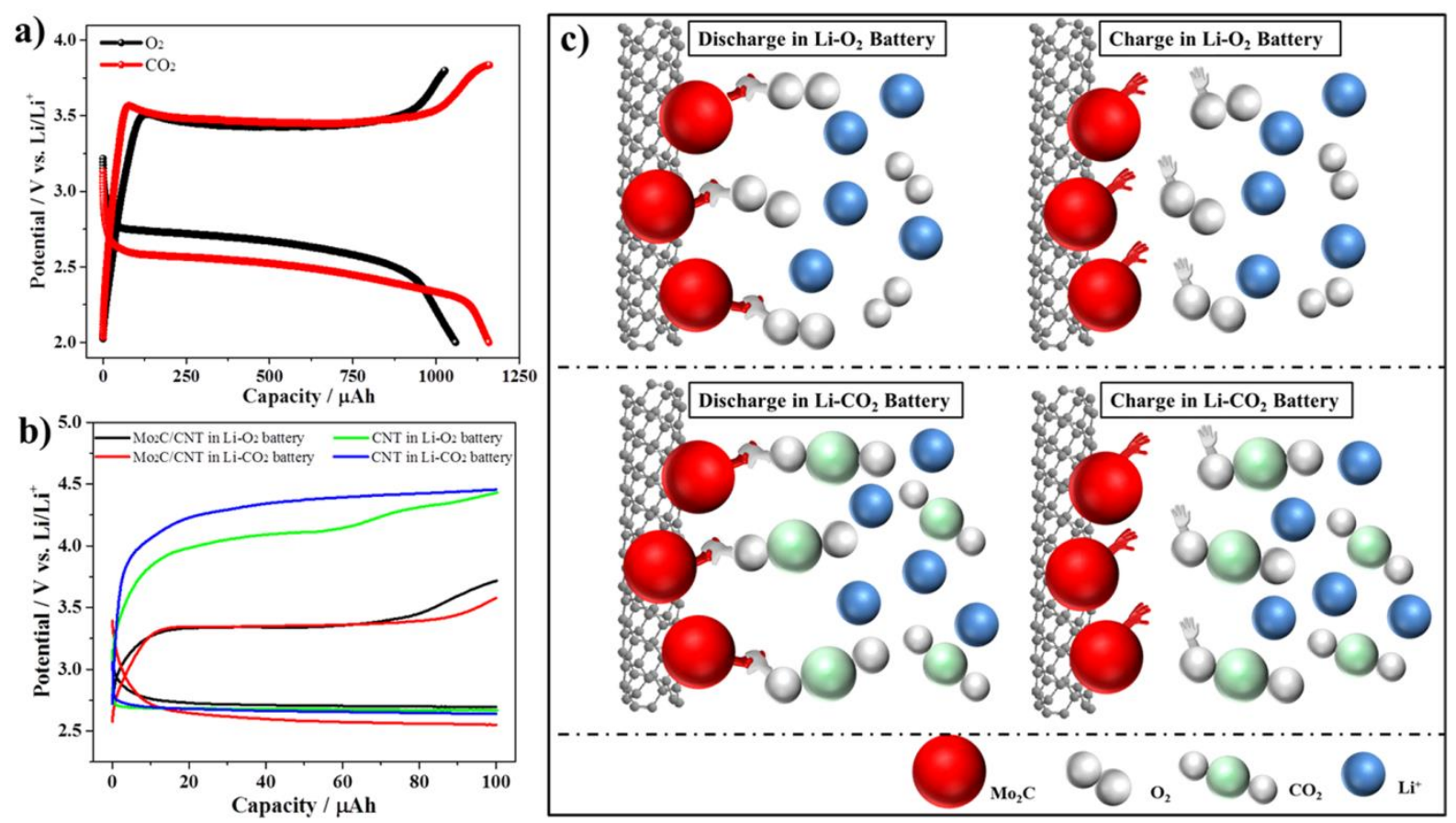

Fig. 4. a) Voltage profiles of $\mathrm{Mo}_{2} \mathrm{C} / \mathrm{CNT}$ as cathode in full discharge-charge for the $\mathrm{Li}-\mathrm{O}_{2}$ battery and the Li- $\mathrm{CO}_{2}$ battery. b) Voltage profiles of $\mathrm{Mo}_{2} \mathrm{C} / \mathrm{CNT}$ as cathode in cut-off capacity dischargecharge for the $\mathrm{Li}-\mathrm{O}_{2}$ battery and the $\mathrm{Li}-\mathrm{CO}_{2}$ battery. c) Schematic illustration of the stabilization mechanism of $\mathrm{Mo}_{2} \mathrm{C} / \mathrm{CNT}$ in the $\mathrm{Li}-\mathrm{O}_{2}$ battery and the $\mathrm{Li}-\mathrm{CO}_{2}$ battery, showing the formation and cleavage of $\mathrm{Mo}-\mathrm{O}$ bonds between $\mathrm{Mo}_{2} \mathrm{C}$ and intermediate species from reduction of $\mathrm{O}_{2}$ and $\mathrm{CO}_{2}$ on discharge and charge. 

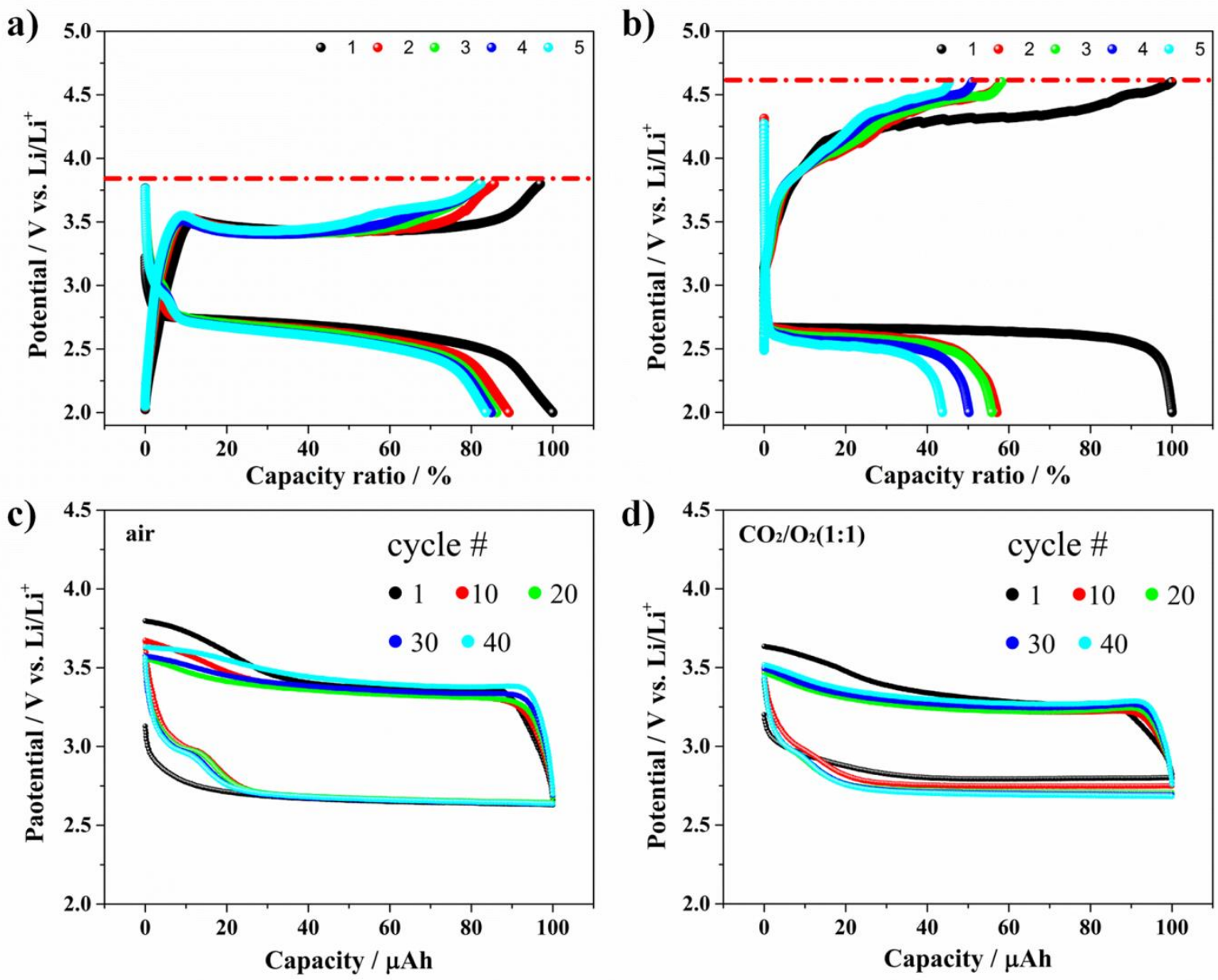

Fig. 5. a) Voltage profiles of $\mathrm{Mo}_{2} \mathrm{C} / \mathrm{CNT}$ in air for the first 5 cycles, with full discharge and recharge between $2.0 \mathrm{~V}$ and $3.8 \mathrm{~V}$, at the current rate of $20 \mu \mathrm{A}$. b) Voltage profiles of CNT in air for the first 5 cycles, with full discharge and recharge between $2.0 \mathrm{~V}$ and $4.6 \mathrm{~V}$, at the current rate of $20 \mu \mathrm{A}$. c) Voltage profiles for selected cycles of $\mathrm{Mo}_{2} \mathrm{C} / \mathrm{CNT}$ in air, with a cut-off capacity of $100 \mu \mathrm{Ah}$, at the current rate of $20 \mu \mathrm{A}$. d) Voltage profiles for selected cycles of $\mathrm{Mo}_{2} \mathrm{C} / \mathrm{CNT}$ in $\mathrm{CO}_{2} / \mathrm{O}_{2}(1: 1)$, with a cutoff capacity of $100 \mu \mathrm{Ah}$, at the current rate of $20 \mu \mathrm{A}$. 